\title{
Muscle Total Lipid, Total Protein, Total Antioxidants, Co Q and Mitochondrial Concentration Analysis in $\mathrm{Coq}_{10}$ Supplemented Broiler Chicken
}

\author{
J. Ramavathi*, P. Selvaraj, P. Visha and V. Thavasiappan \\ Department of Veterinary Physiology, VCRI, Namakkal, India \\ *Corresponding author
}

\section{Keywords \\ Total Lipid, Protein, Antioxidants, Co Q and Mitochondrial concentration}

Article Info

Accepted:

10 July 2020 Available Online: 10 August 2020

\begin{abstract}
A B S T R A C T
Two hundred and forty (240) numbers of day old broiler straight run chicks were wing banded, weighed and randomly allotted to 5 groups 6 replicates of eight chicks each based on the body weight. The treatments were, Basal diet without $\mathrm{CoQ}_{10}$ supplementation, Low energy diet without $\mathrm{CoQ}_{10}$ supplementation, Low energy diet with $20 \mathrm{mg}$ of $\mathrm{CoQ}_{10} / \mathrm{kg}$ diet, Low energy diet with $40 \mathrm{mg}$ of $\mathrm{CoQ}_{10} / \mathrm{kg}$ diet, Low energy diet with $60 \mathrm{mg}$ of $\mathrm{CoQ}_{10} / \mathrm{kg}$ diet. Muscle total lipid was estimated gravimetrically by using Folch method of lipid extraction. The antioxidant ability of muscle was determined by the method described by Benzie and Strain. One gram of muscle tissue was taken and $\mathrm{CoQ}_{10}$ was extracted by using solvents methanol:hexane. Protein content of meat was estimated by kjeldhal method according to procedure described in AOAC. Hepatic mitochondria were obtained by differential centrifugation as outlined by Cawthon et al., (1999). Mitochondrial protein concentration was estimated as per the method of Lowry et al., 1971. There was a significant difference in protein content of the breast muscle was observed between treatment groups and control. The protein accretion on the muscle ranged from 7 to $9 \%$. The result of the present study agrees with the average value of $22 \%$ in breast muscle of broiler chicken.The effect of $\mathrm{CoQ}_{10}$ on muscle lipid did not exhibit any variation. It is understood from the result that $\mathrm{CoQ}_{10}$ on lipid accretion in muscle is negligible. The results of the study clearly proved that antioxidants level was influenced by the level of $\mathrm{CoQ}_{10}$ in the diet. Further the present study also shown that antioxidants status was lower in birds fed less energy in the diet. Our findings agrees with many earlier observations (Littarru et al., 2007), Mates et al., (1999), Kapoor and Kapoor (2013) and Fathi (2015) on antioxidants status due to supplementation of $\mathrm{CoQ}_{10}$. There was no significant difference existed in the mean breast muscle $\mathrm{CoQ}_{10}$ for $\mathrm{T} 3$ and $\mathrm{T} 4$ group of birds. The mean breast muscle $\mathrm{CoQ}_{10}$ was significantly $(\mathrm{P}<0.05)$ lower in low energy diet without $\mathrm{CoQ}_{10}$ supplemented group (T2). The mean muscle mitochondrial protein concentration was significantly $(\mathrm{P}<0.05)$ higher in the $\mathrm{CoQ}_{10}$ supplemented group of birds $(\mathrm{T} 3, \mathrm{~T} 4$ and $\mathrm{T} 5)$ in comparison to $\mathrm{T} 2$ and groups. There was no significant difference in the mean mitochondrial protein concentration of $\mathrm{T} 3, \mathrm{~T} 4$ and $\mathrm{T} 5$ groups of chicken.
\end{abstract}




\section{Introduction}

Coenzyme $\mathrm{Q}_{10}\left(\mathrm{CoQ}_{10}\right)$ is a naturally occurring compound with a ubiquitous distribution in nature. Based on an isoprenoid moiety, the presence of various $\mathrm{CoQ}$ homologs has been confirmed. CoQ10, which has a polyisoprene chain containing 10 isoprene units, was predominant in humans and birds, whereas $\mathrm{CoQ} 9$ was predominant in rats and mice (lbano et al., 2002). Kamisoyama (2010) found that dietary $\mathrm{CoQ}_{10}$ significantly reduced the levels of cholesterol in the egg yolks of laying hens, but the mechanisms underlying this reduction in eggyolk cholesterol have not been identified. In chickens, dietary $\mathrm{CoQ}_{10}$ supplementation reduced broiler chickens susceptibility to ascites, perhaps as a result of improved hepatic mitochondrial function, respiratory chain-related enzyme activities, and the mitochondrial antioxidant activity of $\mathrm{CoQ}_{10}$. Nakamura (1996) stated that fed broiler chicks diets supplemented with coenzyme Q9, an analogue of $\mathrm{CoQ}_{10}$, at $40 \mathrm{mg} / \mathrm{kg}$ and showed that dietary coenzyme Q9 supplementation was beneficial in reducing ascites incidence in broiler chicks.

Geng et al., (2010) reported that the mortality of broilers due to ascites was reduced by Lcarnitine and $\mathrm{CoQ}_{10}$ supplementation alone and in combination the reason may be partially associated with the antioxidative effects of these substances. In broiler chicken higher body weight gain and better feed efficiency with less feed cost per kilogram weight gain was observed in high energy group supplemented with $20 \mathrm{mg}$ of $\mathrm{CoQ}_{10} / \mathrm{kg}$ diet and the dressing percentages, weight of giblet, liver, spleen, abdominal fat, intestinal length were not significantly altered by CoQ10 supplementation but the heart weight, gizzard weight and ascites heart weight (AHI) were significantly decreased due to $\mathrm{CoQ}_{10}$ supplementation (gopi et al., 2014).
Reactive oxygen species (ROS) are mainly mitochondrial derived and directly affects the vascular remodeling and also causes pulmonary hypertension and growth rate (Bautista-Ortega et al., 2010). Broilers fed to an energy dense diet were more susceptible to oxidative stress (Cardoso et al., 2010), whereas restricted feeding decreases oxidative damage (Ozkan et al., 2010). However, an early feed restriction has severely affected the growth performance and lipid metabolism in broilers (Zhan et al., 2007; Saber et al., 2011).

\section{Materials and Methods}

Two hundred and forty (240) numbers of day old broiler straight run chicks were wing banded, weighed and randomly allotted to 5 groups 6 replicates of eight chicks each based on the body weight.

The treatments were $\left(\mathrm{T}_{1}-\mathrm{T}_{5}\right)$, Basal diet without $\mathrm{CoQ}_{10}$ supplementation, Low energy diet without $\mathrm{CoQ}_{10}$ supplementation, Low energy diet with $20 \mathrm{mg}$ of $\mathrm{CoQ}_{10} / \mathrm{kg}$ diet, Low energy diet with $40 \mathrm{mg}$ of $\mathrm{CoQ}_{10} / \mathrm{kg}$ diet, Low energy diet with $60 \mathrm{mg}$ of $\mathrm{CoQ}_{10} / \mathrm{kg}$ diet.

\section{Muscle total lipid}

Muscle total lipid was estimated gravimetrically by using Folch method of lipid extraction. One gram muscle tissue was homogenized with $10 \mathrm{ml}$ of Folch solution $\left(\mathrm{CHCl}_{3}: \mathrm{CH}_{3} \mathrm{OH}\right)$. The chloroform layer containing lipid was taken in preweighed petridishes. The contents were dried in a hot air oven until the consequent weights were uniform. The results were expressed in \%.

\section{Estimation of muscle protein}

Protein content of meat was estimated by kjeldhal method according to procedure described in AOAC (1995). 


\section{Estimation of muscle mitochondrial protein}

Approximately $2 \mathrm{~g}$ of muscle tissue was taken and mitochondrial protein concentration was estimated.

\section{Preparation of mitochondria}

Hepatic mitochondria were obtained by differential centrifugation as outlined by Cawthon et al., (1999). Approximately $2 \mathrm{~g}$ of muscle tissue was suspended in $5 \mathrm{ml}$ of isolation media (PH 7.4) containing $220 \mathrm{mM}$ d-mannitol, 70mM sucrose, 2mM HEPES, 0.5 $\mathrm{mg} / \mathrm{ml} \mathrm{BSA}$ and $1 \mathrm{mM}$ Ethylene glycol-bis beta amino ethyl ether NNN'N' tetra acetic acid (EGTA). The tissue was homogenized with a hand driven glass-teflon homogenizer. Aliquots were transferred into centrifuge tubes \& centrifuged twice for $10 \mathrm{~min}$ at $600 \mathrm{~g}$. The pellets containing nuclei and cell debris were discarded and the supernatant was centrifuged at $7750 \mathrm{~g}$ for $15 \mathrm{~min}$.

The mitochondrial pellets were resuspended in an isolation buffer (PH 7.0) containing $220 \mathrm{mM}$ d-mannitol, $70 \mathrm{mM}$ sucrose, $2 \mathrm{mM}$ HEPES and $0.5 \mathrm{mg} / \mathrm{ml} \mathrm{BSA}$ and were washed twice. Mitochondria were resuspended in incubation media $(210 \mathrm{mM}$ d-mannitol, $70 \mathrm{mM}$ sucrose, $2 \mathrm{mM}$ HEPES and 10mM succinate) and placed on ice.

\section{Estimation of mitochondrial protein}

Mitochondrial protein concentration was estimated as per the method of Lowry et al., (1951). Briefly, standard curve was prepared by using BSA as standard at different concentration. $200 \mu \mathrm{L}$ of sample was added with $2 \mathrm{ml}$ of alkaline copper sulphate solution and then $0.2 \mathrm{ml}$ of Folin Ciocaltaeau was added in a test tube. The reagents were incubated for $30 \mathrm{~min}$. The absorbance was recorded by using spectrophotometer at $660 \mathrm{~nm}$.

\section{Estimation of muscle total antioxidants}

The antioxidant ability of muscle was determined by the method described by Benzie and Strain (1996).

FRAP reagent:

0.3M Sodium acetate buffer (PH 3.6)-25ml

$0.01 \mathrm{~N}$ 2,4,6-tripyridyl-S-triazine (TPTZ) in $0.04 \mathrm{M} \mathrm{HCl}-2.5 \mathrm{ml}$

0.02M ferric chloride $\left(\mathrm{FeCl}_{3} \cdot 6 \mathrm{H}_{2} \mathrm{O}\right)-2.5 \mathrm{ml}$

$0.5 \mathrm{~g}$ of muscle tissue was homogenized with $5 \mathrm{ml}$ of phosphate buffer saline and centrifuged at 3000rpm for $15 \mathrm{~min}$. The final muscle extract was used for total antioxidant assay. Briefly, $3 \mathrm{ml}$ of FRAP reagent was prewarmed to $50^{\circ} \mathrm{C}$ and mixed with $100 \mu \mathrm{L}$ of muscle extract. The absorbance of the blue Fe-II-complex at 593nm was recorded using spectrophotometer after $5 \mathrm{~min}$ incubation at 37 ${ }^{\circ} \mathrm{C}$. Total antioxidant in muscle extract was expressed as $\mu \mathrm{mol} / \mathrm{g}$ of muscle tissue.

\section{Estimation of muscle Co Q level}

One gram of muscle tissue was taken and $\mathrm{CoQ}_{10}$ was extracted by using solvents methanol:hexane.. 100 $\mu \mathrm{L}$ of muscle extract, $100 \mu \mathrm{L}$ of Tween $20,1.5 \mathrm{ml}$ of methanol and $1.5 \mathrm{ml}$ of hexane were added to a glass tube. The samples were subjected to mechanical shaking for one min and centrifuged at $1752.8 \mathrm{~g}$ for $10 \mathrm{~min}$ at $10^{\circ} \mathrm{C}$. The residues were evaporated without heating under a flow of nitrogen for $20 \mathrm{~min}$. Then the residues were resuspended in $3 \mathrm{ml}$ of methanol:hexane (2:1). The samples were again homogenized under vortex mechanical shaking for $15 \mathrm{sec}$ and rotary shaking for $15 \mathrm{~min}$. The final solution was used for $\mathrm{CoQ}_{10}$ assay. The absorbance was taken at 340nm in UV spectrophotometer. 


\section{Results and Discussion}

\section{Muscle lipid and protein}

The mean breast muscle protein $(\%)$ was $15.96,16.88,16.63$ and 17.31 for T2, T3, T4 and $\mathrm{T} 5$ respectively compared to 15.77 (\%) in the control group (Table 1). Also, the highest mean muscle protein noticed in the group T5 but no significant difference was observed between $\mathrm{T} 3$ and $\mathrm{T} 4$ group of birds. The reason for this may be due to higher $\mathrm{CoQ}_{10}$ in the muscle but the higher protein content did not reflect upon the body weight. This needs further investigation. The Present study also revealed that lower mean muscle protein in control and low energy diet without $\mathrm{CoQ}_{10}$ supplemented group of birds (T2)

Overall, the protein content was lower in the breast muscle when compared to normal muscle protein of $20-22 \%$. The higher THI recorded throughout the study might be responsible for the reduction in the protein content of the muscle. (Table 1)

The mean breast muscle lipid (\%) was 1.11 , $1.09,1.10$ and 1.08 for $\mathrm{T} 2, \mathrm{~T} 3$ and $\mathrm{T} 5$ respectively as compared with $1.13(\%)$ in the control group of broiler chicken. The effect of $\mathrm{CoQ}_{10}$ on muscle lipid did not exhibit any variation. It is understood from the result that $\mathrm{CoQ}_{10}$ on lipid accretion in muscle is negligible. The observations of our study is in accordance with the earlier workers (Chartrin et al., 2004) and (Mane et al., 2014). The above authors recorded $0.75-1.5 \%$ of fat on an average in breast muscle of broiler chicken.

However, there was a significant difference in protein content of the breast muscle was observed between treatment groups and control. The protein accretion on the muscle ranged from 7 to $9 \%$. The result of the present study agrees with the average value of $22 \%$ in breast muscle of broiler chicken.

\section{Antioxidants}

Table 1 shows, the mean breast muscle antioxidants $(\mu \mathrm{mol} / \mathrm{g})$ were $3.25,5.53,5.54$ and 6.25 for $\mathrm{T} 2, \mathrm{~T} 3, \mathrm{~T} 4$ and $\mathrm{T} 5$ respectively as compared with $4.08(\mu \mathrm{mol} / \mathrm{g})$ in the control group of broiler chicken.

The results of the study clearly proved that antioxidants level was influenced by the level of $\mathrm{CoQ}_{10}$ in the diet. Further the present study also shown that antioxidants status was lower in birds fed less energy in the diet. Our findings agrees with many earlier observations (Littarru et al., 2007), Mates et al., (1999), Kapoor and Kapoor, (2013) and Fathi (2015) on antioxidants status due to supplementation of $\mathrm{CoQ}_{10}$. Many earlier researchers found that $\mathrm{CoQ}_{10}$ supplementation improved antioxidants capacity of broiler chicken and in other animals.

\section{Coenzyme Q}

The mean muscle $\mathrm{CoQ}_{10}(\mathrm{mg} / \mathrm{kg})$ were 7.57 , $8.61,8.91$ and 9.17 in the treatment groups T2 to T5 as compared with $8.78(\mathrm{mg} / \mathrm{kg})$ in the control group of broiler chickens (Table 1).

The mean breast muscle $\mathrm{CoQ}_{10}$ content was significantly $(\mathrm{P}<0.05)$ high in the T5 than T3 and $\mathrm{T} 4$. There was no significant difference existed in the mean breast muscle $\mathrm{CoQ}_{10}$ for $\mathrm{T} 3$ and $\mathrm{T} 4$ group of birds. The mean breast muscle $\mathrm{CoQ}_{10}$ was significantly $(\mathrm{P}<0.05)$ lower in low energy diet without $\mathrm{CoQ}_{10}$ supplemented group (T2).

The supplementation of $\mathrm{CoQ}_{10}$ did not improve $\mathrm{CoQ}_{10}$ content of the breast muscle except in T5. This finding of our study concurs with the observation of low $\mathrm{CoQ}_{10}$ level in breast muscle compared to leg muscle (Krizman et al., 2012). The present study lacks the information on leg muscle $\mathrm{CoQ}_{10}$ level to compare breast muscle. 
Table.1 Mean $( \pm$ S.E) muscle lipid, protein, COQ, Antioxidants, mitochondrial protein concentration of breast muscle fed $\mathrm{CoQ}_{10}$ at graded levels

\begin{tabular}{|c|c|c|c|c|c|}
\hline Treatment & Lipid (\%) & $\begin{array}{l}\text { Protein } \\
(\%)\end{array}$ & $\begin{array}{c}\mathrm{CoQ}_{10} \\
(\mathrm{mg} / \mathrm{kg})\end{array}$ & $\begin{array}{l}\text { Antioxidants } \\
(\mu \mathrm{mol} / \mathrm{g})\end{array}$ & $\begin{array}{c}\text { Mitochondrial protein } \\
(\mu \mathrm{g} / \mathrm{g})\end{array}$ \\
\hline Control & $1.13 \pm 0.24$ & $15.77^{\mathrm{a}} \pm 0.44$ & $8.78^{\mathrm{c}} \pm 0.44$ & $4.08^{\mathrm{b}} \pm 0.18$ & $5.72^{\mathrm{b}} \pm 0.30$ \\
\hline $\mathbf{T} 2$ & $1.11 \pm 0.30$ & $15.96^{\mathrm{a}} \pm 0.31$ & $7.57^{\mathrm{a}} \pm 0.62$ & $3.25^{\mathrm{a}} \pm 0.13$ & $5.27^{\mathrm{b}} \pm 0.27$ \\
\hline T3 & $1.09 \pm 0.21$ & $16.88^{\mathrm{b}} \pm 0.38$ & $8.61^{\mathrm{b}} \pm 0.27$ & $5.53^{\mathrm{c}} \pm 0.28$ & $8.90^{\mathrm{a}} \pm 0.28$ \\
\hline T4 & $1.10 \pm 0.29$ & $16.63^{\mathrm{b}} \pm 0.32$ & $8.91^{\mathrm{c}} \pm 0.48$ & $5.54^{\mathrm{c}} \pm 0.34$ & $8.27^{\mathrm{a}} \pm 0.43$ \\
\hline T5 & $1.08 \pm 0.24$ & $17.31^{\mathrm{c}} \pm 0.43$ & $9.17^{\mathrm{d}} \pm 0.36$ & $6.25^{\mathrm{d}} \pm 0.29$ & $8.54^{\mathrm{a}} \pm 0.27$ \\
\hline
\end{tabular}

Means within the same column bearing different superscripts differ significantly $(\mathrm{P}<0.05)$.

Table.2 Temperature and humidity of poultry house

\begin{tabular}{|c|c|c|c|c|c|c|c|c|c|}
\hline \multirow[t]{2}{*}{ PERIODS } & \multicolumn{3}{|c|}{ TEMPERATURE $\left({ }^{\circ} \mathrm{C}\right)$} & \multicolumn{3}{|c|}{ RH (\%) } & \multicolumn{3}{|c|}{ THI ( $\mathrm{C})$} \\
\hline & $\begin{array}{c}\text { MOR } \\
(6-8 \text { A.M })\end{array}$ & $\begin{array}{c}\text { A.N } \\
(1-2 P . M)\end{array}$ & $\begin{array}{c}\text { EVE } \\
(5-7 P . M)\end{array}$ & $\begin{array}{c}\text { MOR } \\
(6-8 \text { A.M })\end{array}$ & $\begin{array}{c}\text { A.N } \\
(1-2 P . M)\end{array}$ & $\begin{array}{c}\text { EVE } \\
\text { (5-7P.M) }\end{array}$ & $\begin{array}{c}\text { MOR } \\
(6-8 A . M)\end{array}$ & $\begin{array}{c}\text { A.N } \\
(1-2 P . M)\end{array}$ & $\begin{array}{c}\text { EVE } \\
\text { (5-7P.M) }\end{array}$ \\
\hline PRESTARTER & 27.07 & 34.57 & 31.36 & 60.86 & 34.36 & 43.29 & 26.40 & 32.80 & 30.00 \\
\hline 2WKS & \pm 0.54 & \pm 0.27 & \pm 0.50 & \pm 0.48 & \pm 0.36 & \pm 0.39 & \pm 0.44 & \pm 0.23 & \pm 0.43 \\
\hline STARTER & 25.79 & 35.36 & 30.71 & 65.50 & 31.43 & 45.00 & 25.83 & 33.14 & 29.72 \\
\hline 2-4WKS & \pm 0.48 & \pm 0.28 & \pm 0.49 & \pm 0.56 & \pm 0.81 & \pm 0.58 & \pm 0.52 & \pm 0.59 & \pm 0.43 \\
\hline FINISHER & 27.53 & 35.80 & 28.93 & 59.73 & 29.40 & 55.00 & 26.11 & 33.35 & 29.14 \\
\hline 4-6WKS & \pm 0.50 & \pm 0.56 & \pm 0.25 & \pm 0.52 & \pm 0.56 & \pm 0.51 & \pm 0.42 & \pm 0.67 & \pm 0.46 \\
\hline
\end{tabular}


Further investigation in large samples are required to explain the variations between muscles.

\section{Mitochondrial protein}

The mean muscle mitochondrial protein concentration $(\mathrm{mg} / \mathrm{g})$ was $5.27,8.90,8.27$ and 8.54 in the treatment groups $\mathrm{T} 2$ to $\mathrm{T} 5$ as compared with 5.72 in the control group of broiler chickens.

The mean muscle mitochondrial protein concentration was significantly $(\mathrm{P}<0.05)$ higher in the $\mathrm{CoQ}_{10}$ supplemented group of birds (T3, T4 and T5) in comparison to T2 and groups. There was no significant difference in the mean mitochondrial protein concentration of T3, T4 and T5 groups of chicken. On the other hand, the mean mitochondrial protein concentration was significantly $(\mathrm{P}<0.05)$ lower in the $\mathrm{T} 2$ and control group of birds.

The result of the present study agrees with the average value of $22 \%$ in breast muscle of broiler chicken. The literature on muscle lipid and protein level due to supplementation of $\mathrm{CoQ}_{10}$ in broiler chickens was scarce. Hence, a detailed discussion was not attempted.

The results of the study clearly proved that antioxidants level was influenced by the level of $\mathrm{CoQ}_{10}$ in the diet. Further the present study also shown that antioxidants status was lower in birds fed less energy in the diet. Our findings agrees with many earlier observations (Littarru et al., 2007), Mates et al., (1999), Kapoor and Kapoor (2013) and Fathi (2015) on antioxidants status due to supplementation of $\mathrm{CoQ}_{10}$. Many earlier researchers found that $\mathrm{CoQ}_{10}$ supplementation improved antioxidants capacity of broiler chicken and in other animals.

The supplementation of $\mathrm{CoQ}_{10}$ did not improve $\mathrm{CoQ}_{10}$ content of the breast muscle except in T5. This finding of our study concurs with the observation of low $\mathrm{CoQ}_{10}$ level in breast muscle compared to leg muscle (Krizman et al., 2012). The present study lacks the information on leg muscle $\mathrm{CoQ}_{10}$ level to compare breast muscle. Further investigation in large samples are required to explain the variations between muscles.

The result of the present study is in agreement with the findings of Kwong et al., (2002) in rats, Geng et al., (2006) in broilers and Huang et al., (2011) in broilers

\section{References}

Bautista-Ortega, J., Ruiz-Feria, C.A. and Ellis, A. (2010) Cytochemical and immunocytochemical localization of oxidative and nitrosative stress in pulmonary hypertension in lungs of broiler chickens, Gallus domesticus. Microscopy Microanalysis, 16(S2): 964-965.

Benzie, I.F.F. and Strain, J.J. (1996).The Ferric Reducing Ability of Plasma (FRAP) as a Measure of "Antioxidant Power. The FRAP Assay. Anal.Biochem., 239 : 70-76.

Cardoso, A.R., Cabral-Costa, J.V. and Kowaltowski, A.J. (2010). Effects of a high fat diet on liver mitochondria: increased ATP-sensitive $\mathrm{K}$ channel activity and reactive oxygen species generation. $J$. Bioenergetics Biomembranes, 42: 245-253.

Cawthon, D., McNew, R., Beers, K. W. and. Bottje, W. G. (1999). Evidence of mitochondrial dysfunction in broilers with pulmonary hypertension syndrome (ascites): Effect of t-butyl hydroperoxide on hepatic mitochondrial function, glutathione, and related thiols. Poult. Sci., 78:114-124.

Chartrin, P., Berri, P., Duval, E.L., Quentin, M. and Baeza, E. (2005). Lipid and fatty acid composition of fresh and cured-cooked breast meat of standard, certified and label chickens. Arch.Geflugelk.,69(5): 219-225.

Fathi, M., 2015.Effects of coenzyme Q10 supplementation on growth performance, some hematological parameters, plasma enzymes activities in broilers with pulmonary hypertension syndrome 
(PHS).Iran. J. Applied Anim. Sci.,5: 147153.

Geng, A.L. and Guo,Y.M.(2006). Effects of dietary coenzymeQ10 supplementation on hepatic mitochondrial function and the activities of respiratory chain-related enzymes in ascitic broiler chickens. $\mathrm{Br}$. Poult. Sci.,46: 626-634.

Geng, A.L., Guo, Y. and Yuan, J. (2010). Effects of dietar 1-carnitine and coenzyme Q10 supplementation on performance and ascites mortality of broilers. Arch AnimNutr., 58: 473-482.

Gopi, M., Purushothaman, $\mathrm{M}$ and Chandrasekaran, D. (2014). Effect of dietary coenzyme Q10 supplementation on the growth rate, carcass characters and cost effectiveness of broiler fed with three energy levels. Springer Plus, 3: 518.

Huang, B., Yuming, G., Xiaofei, H. and Song, Y. (2011). Effects of coenzyme Q10 on growth performance and heart mitochondrial function of broilers under high altitude induced hypoxia. J. Poult. Sci.,48: 40-46.

Kamisoyama, H., Honda, K., Kitaguchi, K. and Hasegawa, S. (2010). Transfer of dietary coenzyme Q10 into the egg yolk of laying hens. J. Poult Sci., 47: 28-33.

Kapoor, P. and Kapoor, A.K. (2013). Coenzyme Q10-a novel molecule. J. Indian Acad.Clin.Med.14: 37-45.

Krizman, P.J., Prosek, M., Smidovnik, A., Wondra, A.G., Glaser, R., Zelenko, B. and Volk, M. (2012). Poultry products with increased content of CoQ10 prepared from chickens fed with supplemental CoQ10. Ch. 9th. In: Eissa AHA (ed). Trends in Vital Food and control engineering. In. Tech. Rijeka, Croatia., 165-186.

Kwong, L.K., Kamzalov, S., Rebrin, I., Bayne, A.V., Jana, C.K., Morris, P., Forster, M.J and Sohal, R.S.(2002). Effects of coenzyme q10 administration on its tissue concentrations, mitochondrial oxidant generation, and oxidative stress in the rat. Free Radic. Biol. Med., 33: 627-632.

Littaru, G.P. and Tiano, L. (2007). Bioenergetic and antioxidant properties of coenzyme Q10: recent developments. Mol. Biotechnol., 37(1): 31-37.

Lowry O. H., N.J., Rosebrough, A.L., Farr and Randall, R.J. (1951).Protein measurement with the folin phenol reagent. J. Biol, Chem., 193: 265.

Mane, B., Ravikanth, K. and Thakur, A. (2014). Lean meat production in broilers with new polyherbal formulation AV/LMP/10. Indian j. App. res., 4(1): 527-529.

Mates, J.M., Gomez P.C. and De Castro IN (1999).Antioxidant enzymes and human diseases.Clin.Biochem., 32: 595-603.

Nakamura, K., Noguchi, K., Aoyama, T., Nakajlma, T. and Tanimura, N. (1996). Protective effect of ubiquinone (coenzyme Q9) on ascites in broiler chickens.Br. Poult. Sci.,37:189-195.

Ozkan, S., Takma, C., Yahav, S., Sogut, B., Turkmut, L., Erturun, H.andCahaner, A. (2010). The effects of feed restriction and ambient on growth and ascitesmortality of broilers reared at high altitude. Poult. Sci.,89: 974-985.

Saber, N.S., Maheri-Sis, N., Shaddel-Telli, A., Hatefinezhad, K., Gorbani, A. and Yousefi, J. (2011).Effect of feed restriction on growth performance of broiler chickens. Annals. Biol. Res., 2(6): 247-252.

Zhan, X.A., Wang, M., Ren, H., Zhao, R.Q., Li, J.X. and Tan, Z.L. (2007).Effect of early feed restriction on metabolic programming and compensatory growth in broiler chickens. Poult. Sci., 86(4): 654-660.

\section{How to cite this article:}

Ramavathi, J., P. Selvaraj, P. Visha and Thavasiappan, V. 2020. Muscle Total Lipid, Total Protein, Total Antioxidants, Co Q and Mitochondrial Concentration Analysis in Coq10 Supplemented Broiler Chicken. Int.J.Curr.Microbiol.App.Sci. 9(08): 467-473. doi: https://doi.org/10.20546/ijcmas.2020.908.055 